\title{
Early Childhood Education Standard: Towards Quality Early Childhood Education Services in Indonesia
}

\author{
Edi Waluyo ${ }^{a}$, Diana $^{\mathrm{b}}$ \\ Early Childhood Teacher Education Department, Faculty of Education, Semarang State University \\ Jl. Sekaran, Gunung Pati, Semarang, Jawa Tengah 50229 \\ Corresponding e-mail: awaluyowulan@mail.unnes.ac.id, bdiana@mail.unnes.ac.id
}

\begin{abstract}
This study aims to share the nature of quality early childhood education, based on Indonesian national standard. This study is critical with respect to the Indonesian government early childhood service expansion plan. It assumes that without strong commitment to quality, the expansion plan would not achieve its true mission. In this sense, the Indonesian government has launched national standard, namely the Minister of Education and Culture Regulation No. 137 of 2014 on Early Childhood Education Standard. This study moreover perceives that numerous factors might influence the achievement of the minimum standards as required. This study involved 30 ECE centers.
\end{abstract}

Keywords: $\quad$ early childhood education; standard; quality

\section{INTRODUCTION}

Early childhood is a golden period of child development. Studies in the field of neuron-science, psychology, and pedagogy concluded that the children experience rapid growth during that period. To meet the essential needs of children as a whole required services that include a systematic and planned micro, meso, exo and macro environments. This is done so that children can grow and develop optimally according to the stage of development of their age.

In practice, ideal developmental stimulation of the young children, however, is not well implemented. This is because the educators commonly follow the advice of their superiors and/or their leaders Ease of Use. As a result early childhood education curriculum, which aims at facilitating child development, become less effective due to this lack of educator' role in the development of a broader curriculum relevant to the needs their respective educational institutions.

The National Action Plan on Education for All (National Education Forum, 2003: 11) document for example, regulating the quality of early childhood education only in human resources. In fact, educators is only one aspect of quality education. In 2009, the Ministry of Education and Culture published the Regulation No. 58 of 2009 on Early Childhood
Education Standards, but it was not implemented maximally, and was later amended through the Ministry of Education and Culture Regulation No. 137 of 2014, with eight expanded standards.

The commitment to broaden and strengthen early childhood education must also be accompanied by a commitment to comprehensive quality. In this context, the basic information about the quality of early childhood education is growing in the field, both among practitioners and users become very necessary to be extracted as a standard of quality early childhood development in the days to come.

In this regard, the standard of early childhood education is critically important to be explored and need to be assessed in terms of the impacts of this application early childhood institutions.

\subsection{Quality Early Childhood Education Service}

The term 'quality' (kualitas) in Indonesian is absorbed from the term 'quality' in English. Collins Cobuild Dictionary (Sinclair, 2003) refer the word to the following description "quality of something is how good or bad it is", in other words the measure of the good and bad things. 'Quality', according to the dictionary, also means 'nature' or 'characteristics' of something. 
Along with the development of early childhood education, quality has become a central issue (Essa \& Young, 2003). The term "good quality" for example, now is often found in various recent reports (Farquhar, 1993). The strengthening of this issue seems to be triggered by a number of impact studies of early childhood programs. High quality Early Childhood Education service is believed to have long-term impacts which are very positive for the children and their future life.

A large number of research correlates Early Childhood Education quality not only with opportunities for individual. Rather, a growing body of research also concluded a positive correlation between early childhood education quality national economic growth (Dahlberg \& Moss, 2005; Dahlberg, Moss, and Pence, 1999; Hughes \& MacNaughton, 2000). In this context, the document of National Action Plan on Education for All (National Education Forum, 2003) issued by the Indonesian government, for example, calling a child and therefore also early childhood, as a "major development capital" (essential capital of national development).

Indeed, there is a thesis that the quality of early childhood has a huge positive impact both at individual and national level; but which one is the so-called 'quality of early childhood education' remains a difficult question to answer. What are the best early childhood services, a question with no clear answer (Essa\& Young, 2003; Farquhar, 1993). Nevertheless, some of the literature, such as the publication of Essa and Young (2003), Podmore, Meade, and Hendricks (2000), and the association of early childhood America, National Association for the Education of Young Children (2009), propose a number of indicators even though each of these three emphasizes these indicators differently (Table 1).

Essa and Young (2003: 34) believe that quality is a multifaceted thing, "a combination of factors". NAECY emphasize the quality of the individualization and alignment with development programs and the needs of children, which is commonly referred to as "Developmentally Appropriate Practice" (DAP). DAP itself more or less is the application of theories, concepts, and principles of the study of human development (developmental studies) in the practice of early childhood education.
Table 1.The Aspects of Early Childhood Education qualities in the previous studies

\begin{tabular}{|c|c|c|}
\hline $\begin{array}{c}\text { Essa \& Young } \\
\qquad(2003)\end{array}$ & $\begin{array}{c}\text { DAP } \\
\text { (NAEYC, } \\
\text { 2009) }\end{array}$ & $\begin{array}{l}\text { Podmore, } \\
\text { Meade, and } \\
\text { Hendricks } \\
(2000)\end{array}$ \\
\hline $\begin{array}{l}\text { the amount of } \\
\text { groups of } \\
\text { children; }\end{array}$ & $\begin{array}{l}\text { holistic } \\
\text { perspective } \\
\text { on children }\end{array}$ & $\begin{array}{c}\text { Responsive } \\
\text { interaction } \\
\text { between children } \\
\text { and adult }\end{array}$ \\
\hline $\begin{array}{l}\text { qualification of } \\
\text { teachers; }\end{array}$ & $\begin{array}{c}\text { Individual } \\
\text { program }\end{array}$ & $\begin{array}{l}\text { Good ratio of } \\
\text { adult-children }\end{array}$ \\
\hline $\begin{array}{c}\text { teacher- } \\
\text { children ratios; }\end{array}$ & $\begin{array}{l}\text { Activities } \\
\text { sourced from } \\
\text { the children's } \\
\text { initiative }\end{array}$ & Group size \\
\hline $\begin{array}{l}\text { incorporation } \\
\text { of children of } \\
\text { various ages } \\
\text { background; }\end{array}$ & $\begin{array}{c}\text { Play as a } \\
\text { learning tool }\end{array}$ & $\begin{array}{l}\text { Training and } \\
\text { education for } \\
\text { staff }\end{array}$ \\
\hline $\begin{array}{l}\text { alignment with } \\
\text { child } \\
\text { development } \\
\text { program }\end{array}$ & $\begin{array}{l}\text { Classes are } \\
\text { flexible and } \\
\text { stimulating } \\
\text { atmosphere }\end{array}$ & Stability of staffs \\
\hline $\begin{array}{l}\text { teacher-child } \\
\text { interaction } \\
\text { patterns; }\end{array}$ & $\begin{array}{l}\text { A curriculum } \\
\text { that includes } \\
\text { all aspects of } \\
\text { development }\end{array}$ & $\begin{array}{l}\text { The clarity of } \\
\text { what becomes } \\
\text { the focus of the } \\
\text { program }\end{array}$ \\
\hline $\begin{array}{l}\text { consistency of } \\
\text { educators; }\end{array}$ & $\begin{array}{l}\text { Learning by } \\
\text { doing }\end{array}$ & $\begin{array}{l}\text { The peer group } \\
\text { harmony }\end{array}$ \\
\hline $\begin{array}{l}\text { appreciation } \\
\text { and attention to } \\
\text { [the welfare of] } \\
\text { educators; }\end{array}$ & $\begin{array}{l}\text { Children are } \\
\text { free to choose } \\
\text { what to learn } \\
\text { and how to } \\
\text { learn }\end{array}$ & $\begin{array}{l}\text { Communication } \\
\text { with parents }\end{array}$ \\
\hline $\begin{array}{c}\text { physical } \\
\text { environment; }\end{array}$ & $\begin{array}{l}\text { Sustainable } \\
\text { evaluation for } \\
\text { each } \\
\text { individual and } \\
\text { the program } \\
\text { as a whole }\end{array}$ & $\begin{array}{c}\text { Staffs salary and } \\
\text { good workplace } \\
\text { environment }\end{array}$ \\
\hline $\begin{array}{c}\text { Parental } \\
\text { involvement. }\end{array}$ & $\begin{array}{l}\text { Partnership } \\
\text { with parents }\end{array}$ & $\begin{array}{c}\text { Safe and healthy } \\
\text { physical } \\
\text { environment }\end{array}$ \\
\hline
\end{tabular}

The issue of quality seems to be a central issue in the discourse of education. This is evident from the fact that almost all the publications in the field of education, both by government and independent bodies and individuals, within and outside the country, almost all address quality issues.

\subsection{Early Childhood Education Standard}

Early Childhood Education (ECE) is the most fundamental education for the child's development in the next period that will be determined by a variety of meaningful stimulation given from an early age. Early age in life is the golden time to provide encouragement or effort to develop, so that children can develop optimally. 
Law No. 20 of 2003 on National Education System (Article 1: point 14) states that early childhood education is an approach to development that is aimed at children from birth to age of 6 years conducted through stimulation of education to help the growth and development of the physical and spiritual wellbeing of children, so that they have learning readiness in entering the next levels of education. The legislation mandates that education should be prepared in a planned and holistic concept as the basis for a child's further education.

The Government of Indonesia in the course development of early childhood education has issued two standards, namely: Decree No. 58 in 2009 and The Minister of Education and Culture regulation No. 137 in 2014. These standards are used as the standard in the development of quality early childhood education institutions in Indonesia.

Early Childhood Education standards are the criteria of the management and implementation of early childhood education in the whole territory of the Republic of Indonesia which consists of: the standard of developmental achievement, standard of learning contents; standard of learning process; standard of assessment; standard of teachers and personnel; standard of facilities and equipment; standard of management; and, standard of finance. (The Minister of Education and Culture regulation No. 137 of 2014). By implementing these eight standard comprehensively, it is expected purpose of early childhood education to facilitate the child's holistic and optimum development, as mandated by the 2003 Education Law (Article $1: 14)$ can be met. To emphasize only one aspect of quality and/or on aspect of child's development is philosophically opposed to the thru intent and purpose of early childhood education itself (Formen, 2008).

Early Childhood Education standards aimed at ensuring the quality of early childhood education in order to provide the basis for:

a. Providing education stimulation in helping the growth and development of children in accordance with the physical and spiritual attainment level of child development;

b. Optimizing the development of children in a holistic and integrative way; and prepare for the formation of attitudes, knowledge, and skills of children.

\section{RESEARCH METHODOLOGY}

This study intended to explore the construction of "Aiming for The Quality Early Childhood Education Services based on the early childhood education standards" according to the head / manager of early childhood, parents, teachers and students. Given the wide scope of themes and size of the population involved in early childhood education, specifically the study took in the city of Semarang, Central Java Province. In general, for attempting to uncover the whole perspective of research subjects, this study used participatory explorative approach, or 'coconstructive', in which the knowledge and understanding of the issues examined jointly built between the subject and the researcher (Blaise, 2005).

\section{RESULT AND DISSCUSSION}

\subsection{Early Childhood Education Quality Services}

The Minister of Education and Culture Regulation No. 137 of 2014 on early childhood education standards are the criteria of the management and implementation of early childhood education throughout the territory of Indonesia which consists of: the standard of developmental achievement, standard of learning contents; standard of learning process; standard of assessment; standard of teachers and personnel; standard of facilities and equipment; standard of management; and, standard of finance.

The learning process should be conducted in an interactive, inspiring, fun, challenging way, in order to motivate learners participating actively and provide enough space for innovation, creativity and independence in accordance with their talents, interests, as well as physical and psychological development of learners. The learning process will be optimized if supported by the approach according to the needs and interests of children.

Early childhood education institution seeks to provide the best service to improve the quality of schooling. Each early childhood institutions have benchmarks that vary depending on the quality of the institution. The following table shows the options of preschool principals, teacher and parents involved in this 
study focus group discussion (FGD), about the quality of early childhood education based on The Minister of Education and Culture regulation No. 137 of 2014 on early childhood education standards.

Table 2. Research Results

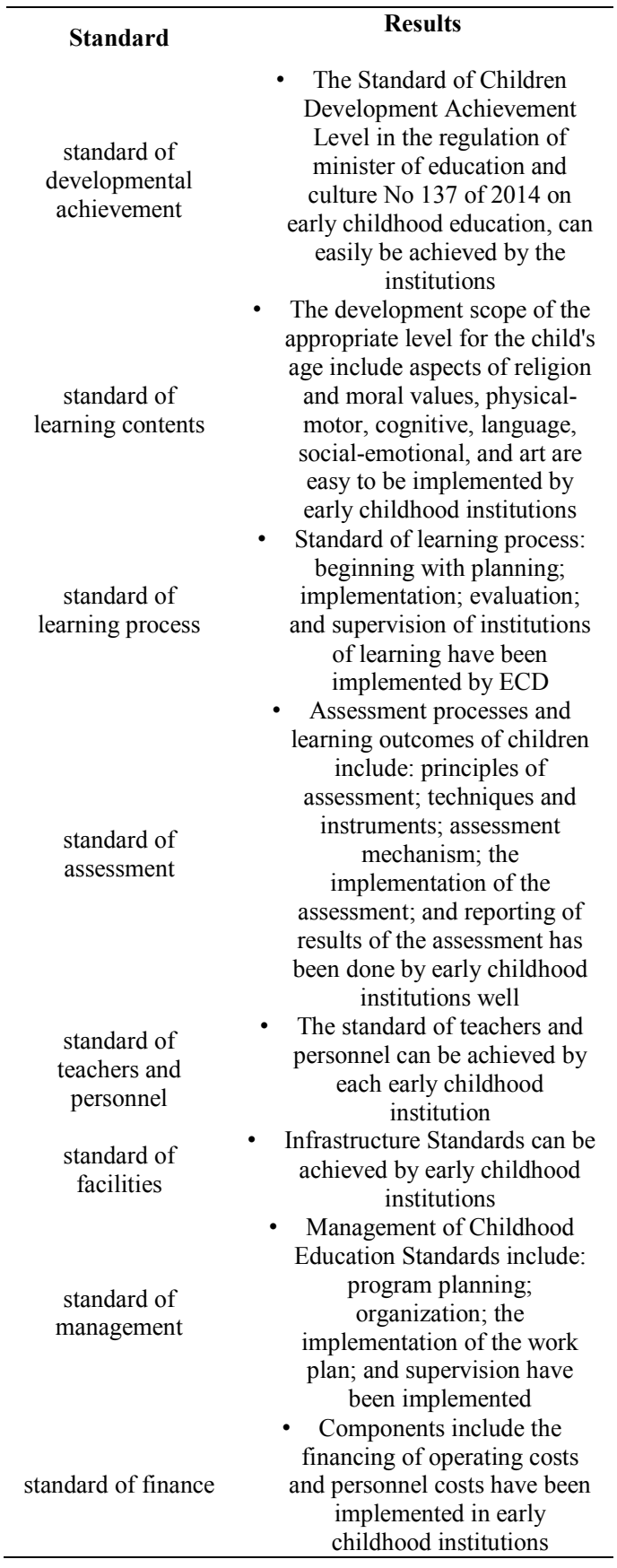

The achievements in quality early childhood education standards is easy. It requires strong efforts by each Early Childhood institution. In order to establish a quality institution, early childhood institutions should be able to optimize the educators who are pillar of education in the institution. Based on research on the regulation of minister of education and culture No 137 of 2014 on Standards for Early Childhood Education:

- Each early childhood institutions is able to achieve ECD Standards easily

- However, the above statement cannot be the guarantee of a quality early childhood education

The success of an institution in improving the quality of early childhood education cannot be separated from the participation of all components in early childhood education institution. Therefore, the participation of various sectors is critical in supporting the achievement of quality childhood institutions.

\section{CONCLUSION}

Based on the results and discussion on the regulation of minister of education and culture No. 137 of 2014, each standard can be achieved by early childhood institutions. Achievement of these standards has not impacted optimally to the achievement of quality early childhood institutions.

\section{RECOMMENDATION}

Develop the standards of early childhood education with early childhood program design based on the characteristics of early childhood institutions such as the public, national, religious, and others.

Provide space on each institution to develop a curriculum that is predictive and according to need. Quality early childhood education institutions should be defined contextually and flexibly, not merely predetermined and top-down. On the other hand, the potential quality model made it difficult for practitioners to achieve intrinsic quality. (Rokhman, 2016: 22)

\section{REFERENCES}

[1] Blaise, M. (2005).Playing It Straight: Uncovering Gender Discourse in The Early Childhood Classroom. New York: Routledge.

[2] Dahlberg, G., \& Moss, P. (2005).Ethics and Politics in Early Childhood Education. New York: RoutledgeFalmer.

[3] Essa, E., \& Young, R. (2003).Introduction Early Childhood Education. Scarborough, Ontario: Thomson \& Nelson. 
[4] Farquhar, S.-E.J. (1993).Constructions of Quality in Early Childhood Centers.Unpublished Doctoral Thesis, University of Otago.

[5] Formen, A. (2008). The Political Landscape of Early Childhood Education in Indonesia. Unpublished Master Thesis, Monash University, Melbourne.

[6] National Association for the Education of Young Children. (2009). Position Statement: Developmentally Appropriate Practice in Early Childhood Programs Serving Children from Birth through Age 8. National Association for the Education of Young Children.

[7] National Education Forum. (2003). National Plan of Action: Indonesia's Education for All 2003/2015: Chapter 2 Early Childhood Education and Care. Retrieved March 19, 2007, from http://portal.unesco.org/education/en/files /22302/10958557103indonesia1.pdf/indo nesia1.pdf

[8] Podmore, V. N., Meade, A., \& Hendricks, A. K. (2000). Aspect of Quality in Early Chidlhood Education. Wellington: New Zealand Council for Educational Reserach.

[9] Rokhman, F (2016) Prosiding Konaspi VIII 2016. Website: http://seminars.unj.ac.id/konaspi/file/Pros iding\%20KONASPI\%20VIII\%202016.p df

[10] Sinclair, J. (Ed.). (2003). Collins Cobuild Advanced Learner's English Dictionary (4th ed.).

[11] Permendikbud Nomor 137 tahun 2014. Tentang Standar PAUD

[12] Undang-Undang RI No 20 in 2003 National Educational System. Jakarta: Departement. 